Part III:

Control of Elections and Electoral Laws 



\title{
Judicial Review of Elections: The Egyptian Experience
}

\author{
Yussef Auf
}

\begin{abstract}
In line with adopting the Egyptian Constitution of 1923, which paved the way for the first-ever pluralistic elections in the history of modern Egypt, the judicial bodies have been a major player in deciding not only on the election's results and validity, but also on the electoral laws in terms of its constitutionality and legitimacy. While in Egypt the administrative courts decide in queries about the election's procedures, the Court of Cassation, Egypt's highest court in the general judiciary, decides on the validity of the MP's memberships itself. Over time, the Supreme Constitutional Court has frequently been interacting with the electoral issues by deciding on the legitimacy and constitutionality of the electoral laws and regulations. This has been done by judicial review prior to the issuance of the law, and by judicial review after the law's promulgation. This chapter discusses and illustrates the role that has been played over decades by various courts concerned with electoral disputes in Egypt.
\end{abstract}

\section{Introduction}

In 1923, Egypt witnessed the issuance of its first modern, comprehensive, and progressive constitution. The latter established two chambers of parliament, which was a novelty, and pushed toward the first multi-party parliamentary elections. Since then, Egypt has been conducting public elections on a semi-regular basis, during the monarchy era, and after the 1952 military action, with some major differences in terms of the election's nature between the two eras. Taking this into account, the electoral history of modern Egypt extends for around a century, and judicial bodies played an important role in relation to elections, i.e. parliamentary elections, presidential elections, local municipalities elections, and public referenda.

The judicial bodies in the Egyptian judicial establishment are: a) the Supreme Constitutional Court (SCC), established in 1969, which adjudicates on the constitutionality of laws and regulations; b) the Administrative Judiciary, established in 1945 , with its jurisdiction over administrative 
decisions; and finally, c) the Court of Cassation, the highest court in the General Judiciary body established in 1931, authorized to decide on the validity of the MP's memberships with regard to elections.

This chapter illustrates the role that has been played by various courts and judicial bodies in Egypt interacting with elections, with reference to election laws or disputes, starting with the Supreme Constitutional Court which adjudicates on the constitutionality of the electoral laws, unlike the other two judicial bodies, namely the Court of Cassation, and the administrative courts, which adjudicate on the electoral disputes.

\section{Electoral laws: The Supreme Constitutional Court}

As mentioned earlier, the SCC was established in the late sixties, with its competencies prescribed for in consecutive constitutions and Law 48 of 1979 Governing the Operations of the Supreme Constitutional Court of Egypt (SCC Law). Since the 1971 Constitution, the major competency of the Egyptian SCC is to decide on the constitutionality of laws and regulations.

Article 192 of the 2014 Constitution provides:

"The Supreme Constitutional Court is exclusively competent to decide on the constitutionality of laws and regulations, interpret legislative texts, and adjudicate in disputes related to the affairs of its members, in disputes between judicial bodies and entities that have a judicial mandate, in disputes pertaining to the implementation of the two final contradictory rulings, one of which is issued by any judicial body or an agency with a judicial mandate and the other issued by another body, and in disputes regarding implementation of its rulings and decisions."

Additionally, Law 48 of 1979 of the SCC, Article 25, provides for:

"The Supreme Constitutional Court shall have exclusive jurisdiction over the following: First: judicial review over the constitutionality of laws and regulations".

Thereunder, the SCC practices its role regarding elections by deciding on the constitutionality of electoral laws that govern elections. Hence, the only way that the SCC has influenced electoral activities is through this constitutionality jurisdiction. In other words, the SCC has no competency over deciding whether the electoral process is legitimate or not, or to approve the results of an election. Based on the legal framework that governs the SCC's jurisdiction, the latter used to practice exclusively the 
post-enactment (concrete) judicial review until 2005, where the Court considered, for the first time, a pre-enactment judicial review for the then 2005 Presidential Elections Bill.

\subsection{The SCC post-enactment judicial review for electoral laws}

Before presenting some examples of constitutional disputes, regarding election laws, it is worth explaining that the constitutional cases reach the SCC through two main channels. One of the channels stated in the SCC Law in Article 29, is referral by an ordinary court, including all courts of General Judiciary (civil, criminal, labor, etc. circuits) and Administrative Judiciary. This referral mechanism opens the door for the ordinary court's judges, in the course of a judicial proceeding, to raise issues of constitutionality and refer it to the Constitutional Court if they (as a court) believe that the legislative text to be applied in the ongoing case violates the Constitution. The second mechanism is through a challenge by a dispute's party (whether the plaintiff or the defendant) in a specific case considered by an ordinary court as in the first mechanism, the challenging party believes that the legislative text that the court will/may apply is in contrary with a provision or more in the Constitution.

The SCC practices its competence of judicial review exclusively, i.e. the SCC is the only court in the Egyptian judicial system that is tasked to decide on the constitutionality of laws and regulations. This explains why a constitutional question must be referred, in all cases, to the SCC. On the other hand, access to the SCC is only permitted through a specific ordinary law suit, considered by an ordinary court, and through a decision by these ordinary courts accepting the parties' request to appeal to the SCC for a constitutional challenge.

Thus, the SCC's decision over the constitutionality of electoral laws comes on the occasion of initial litigation brought before an administrative court (or the Supreme Administrative Court). The latter Court's task is to decide on the legitimacy of one or more of the administrative decisions (for instance, decisions by the high committee for parliamentary elections). The court refers the case to the SCC when a constitutional challenge has been raised. 


\subsubsection{The constitutionality of laws on parliament}

In the mid-eighties, the SCC had its first landmark decision issued in this regard. The Court ruled that Articles 5, 6/1 and 17/1 of the People's Assembly Law 38 of 1972, as amended by Law No. 114 of 1983, were unconstitutional. ${ }^{1}$ The decision came after two and half years from filing the lawsuit before the SCC on December 12, 1984, when the People Assembly (PA, the then lower parliament chamber) was already elected in mid-1984. The PA election was based on the PA Law, which stated that all Parliament seats to be elected through political parties' lists only. Hence, the law deprived the individuals (non-partisans) of their right to run for parliamentary elections. That was the reasoning on which the SCC grounded its above decision, considering that the law is unconstitutional.

The Court said that as the aforementioned provisions limit the candidacy rights to those who belong to political parties,

"and thus deprive others of that right without regard to its nature and its requirements. The right of candidacy is one of the public rights guaranteed by the Constitution in Article 62, and thus depriving a group of this right entails a waste of its origin and violates the principles of equality of opportunity and equality before the law and thus constitutes a violation of Articles 8, 40, 62 of the [1971] Constitution". ${ }^{2}$

According to Article 48 of the SCC Law 48 of 1979, all Court decisions are final and cannot be challenged. Moreover, Article 49 states: "The judgments of the Supreme Constitutional Court in constitutional cases, and its interpretation decisions are binding on all State authorities and erga omnes."

Considering the legal effect of the SCC decisions, the Court's decision in 1987 that deemed some of the PA's law articles as unconstitutional has led to the dissolution of the 1984 People's Assembly by means of a presidential decree to implement the SCC decision. The five-year term would have elapsed by mid-1989.

A second decision by the SCC in the same direction followed in mid-1990. ${ }^{3}$ The challenge was directed toward the People's Assembly Law 38 of 1972 but with regard to its amendments by Law 188 of 1986 . These

1 See Case 131 for the 6th Judicial Year, Supreme Constitutional Court, session May 16, 1987.

2 http://hrlibrary.umn.edu/arabic/Egypt-SCC-SC/Egypt-SCC-131-Y6.html.

3 See Case 37 for the 9th Judicial Year, Supreme Constitutional Court, session May 19, 1990. 
amendments were made to ease the criticism triggered by the previous amendments (Law 114 of 1983, on which the 1984 parliamentary elections were held, and was later deemed unconstitutional by the SCC), and to amend the electoral system. After dissolving the 1984 elected People's Assembly in May 1987, a new election was held later in the same year under Law 188 of 1986 . The electoral system introduced by virtue of that law was distributing the seats allocated for each constituency as one seat for individual candidates, and the remaining seats were reserved for the party lists.

The SCC, when reviewing the constitutionality of the election mode resulting from the amendments by Law 188 of 1986, found that the reading of Article 5 bis

"indicates the legislator's intention to allocate one seat, for the individual electoral system in each electoral district, to be contested between the individual candidates and members of political parties. On the other hand, allocated several seats in each electoral district exclusively for party lists candidates... explicitly constitutes a violation of the right of "non-partisan" individual candidates to run for elections on the basis of equality and equal opportunity with other partisan candidates, a violation which led to discrimination between the two categories of candidates and is in contrary with Articles 8, 40 and 62 of the [1971] Constitution." 4

The SCC thus considered Article 5 bis of the law unconstitutional. In this decision, the SCC explicitly addressed the consequence of its decision regarding the legitimacy of the electoral process of the PA itself by stating that:

"Whereas the election of the People Assembly was based on an 'unconstitutional' law, as found by the Court, hence, the People Assembly formation itself is void since its election."

For the second time, the PA was dissolved in October 1990 to implement the binding SCC decision.

The aforementioned decisions by the SCC in 1987 and 1990, had led the government, the de-facto legislative authority, to recede from adopting a list electoral system that allocates a big portion of the seats of the People's Assembly seats to partisan lists. The PA law was then amended to enforce an absolute individual electoral system which governed the five parliamentary elections that took place from 1990 to 2010. In this regard, it is obvious how much impact the SCC's decisions have made on the rules

4 http://hrlibrary.umn.edu/arabic/Egypt-SCC-SC/Egypt-SCC-37-Y9.html. 
of the electoral system that has been governing parliamentary elections in Egypt for decades.

While there is no evidence that these decisions by the SCC were politically motivated - considering the solid reasoning of the Court decisions - however, these decisions reveal the failure of the authorities in Egypt for years, to draft a convenient and balanced electoral system in line with the Constitution, and make all the negative, intended and unintended consequences that had been caused by dissolution of parliament by the Court's decision more obvious. Worth mentioning here is that the two parliaments elected in 1984 and 1987, and dissolved in 1987 and 1990 consecutively, included significant opposition (specially Al-Wafd party and the Muslim Brotherhood). With the individual electoral system in place since 1990, the successive parliaments had seen almost no opposition (except in the People's Assembly of 2000 and the one of 2005, which is considered due to the judicial oversight throughout these elections).

Adopting the individual electoral system for the parliamentary elections in Egypt is, in fact, considered to be a major obstacle to the strengthening of political life, the support of political parties and the spread of pluralism. Successive governments in Egypt have been relying on the individual system to control elections, exclude opposition and eventually marginalize the role of parliament.

The third and latest decision by the SCC that caused the dissolution of the parliament was in June 2012. After the January 2011 uprising, the longstanding demand by political forces in Egypt to apply a "list electoral system" had been met. The de-facto authority governing the country at that time, the Supreme Council for Armed Forces (SCAF), amended the People Assembly Law 38 of 1972 (by Laws 108 of 2011, 120 of 2011 and 123 of 2011) that paved the way for "closed partisan lists" to run for two-thirds of the parliamentary seats, and the remaining one-third reserved for the individual system, whether the individuals are independent or partisan.

The SCC ruled that the amendments of the People Assembly Law introduced in 2011 are unconstitutional. ${ }^{5}$ The reasoning for the unconstitutionality of the amendments introduced in 2011 did not differ much from those of the 1987 and 1990 decisions. Moreover, the Court evoked its 1990 precedent stating that:

5 See Case 20 for the 34th Judicial Year, Supreme Constitutional Court, session June 14, 2012. 
"Whereas the election of the people Assembly [late 2011/2012] was based on the 'unconstitutional articles, as found by the Court, hence, the People Assembly's entire formation is void since its election."

It would not be an exaggeration to state that the SCC's June 2012 decision was a huge turning point in the transitional period of the post-January 2011 uprising. ${ }^{6}$ The decision came less than five months after the first PA meeting in late January 2012, and only two days before the run-off round of presidential elections on June 16 and 17, 2012. A major criticism to the SCC's 2012 decision was directed to the timing of its issuance, considering that the SCC took around two and half years to issue each of the two previous judgments which caused the dissolution of the People's Assembly in 1987 and 1990, while it only took a few months to decide on the 2012 case. Worth noting here is that the 2012 People's Assembly was dominated by Islamist parties, 43\% for the Muslim Brotherhood, and 25\% for the Salafist Al-Nour Party. Many doubts have been raised, then, regarding the decision and its timing, especially by the "Islamist Parties", and seen as a crucial factor for the political polarization the country had been through, and which led, eventually, to the July 2013 events. ${ }^{7}$

No evidence is needed to prove the deep impact of dissolving a parliament as consequence of a court's decision, and specifically in a semi-presidential system as in Egypt. In view of this, some political and academic voices have been calling for fixing this distorted status and proposed by proposing two solutions. The first was to change the SCC competency, by amending its law, in order to limit the SCC to pre-enactment review of election laws and to avert any post-enactment judicial review of these. This mechanism would guarantee that all election laws are promulgated after examining its constitutionality; hence, there would no longer be a chance to dissolve any parliament as the SCC has no competency to re-examine the election laws after being enforced. This pre-enactment mechanism has actually happened at some instances since 2005, which will be discussed later in this chapter. The second possible solution (assuming that the SCC practiced its regular post-enactment judicial review competence and ruled that election law is unconstitutional) was to limit the SCC ruling effects to delegitimize the law itself and declaring its unconstitutional articles as void, without extending these effects to dissolve the People's Assembly which should continue its constitutional term. A close compara-

6 http://www.ifes.org/sites/default/files/egypt_scc_decisions_august9.pdf: 4 and 5.

7 https://www.theguardian.com/world/2012/jun/14/egypt-parliament-dissolved-supre me-court. 
tive example of this suggested mechanism comes from the German Federal Constitutional Court (FCC). The German FCC ruled that, "Federal Voting Machine Ordinance of September 3, 1975 [amended on 20 April 1999] is not compatible with Article 38 in conjunction with Article 20.1 and 20.2 of the Grundgesetz (Basic Law) insofar as it does not ensure monitoring that complies with the constitutional principle of the public nature of elections".

The German FCC based its verdict on:

"The principle of the public nature of elections emerging from Article 38 in conjunction with Article 20.1 and 20.2 of the Basic Law requires that all essential steps in the elections are subject to public examinability unless other constitutional interests justify an exception." and "When electronic voting machines are deployed, it must be possible for the citizen to check the essential steps in the election act and in the ascertainment of the results reliably and without special expert knowledge" .

In this latter case, although the German FCC ruled that an election-related law is unconstitutional, it did not deem the elections of the 16th German Bundestag as void.

\subsubsection{Judicial administration for elections}

Since 1952, parliamentary elections in Egypt have been described by critics as an unfair process that lacks integrity and is controlled by security apparatuses with widespread fraud. The situation has changed to a large extent during the 2000 parliamentary elections where the Judiciary supervised the election by virtue of a Supreme Constitutional Court decision. Article $88 / 2$ of the 1971 Constitution (before its amendment in 2007) provides for: "The rules on the organization of the ballot shall be determined by law, while the ballot shall be conducted under the supervision of members of a judicial body."

A constitutional challenge to the Law on Regulating the Exercise of Political Rights 73 of 1956 (arts. 24, 34 and 35) reached the Supreme Constitutional Court on January 21, 1991. ${ }^{9}$ In this constitutional case, the Court ruled that these articles are unconstitutional as the regulation

8 Bundesverfassungsgericht, Judgment of the Second Senate of March 3, 2009 - 2 BvC 3/07 - paras. (1-166), http://www.bverfg.de/e/cs20090303_2bvc000307en.html.

9 http://hrlibrary.umn.edu/arabic/Egypt-SCC-SC/Egypt-SCC-11-Y13.html. 
"allows the appointment of the presidents of the electoral sub-committees from those who are not members of the judicial bodies [judges]." The SCC in its reasoning stated that the right interpretation of Article 88 of the Constitution necessitates that each ballot box should be directly supervised by a judicial body member. With this decision, issued on July 8,2000 , the principle of "a judge for each ballot box" was established.

On the basis of the binding nature of the SCC verdicts, the then President of the Republic amended the law on regulating the exercise of political rights allowing "full" judicial supervision for parliamentary elections. Although the law and the political regime, in practice, did not allow the judiciary to manage the electoral process fully and completely, the degree of integrity and the level of public trust had been raised to unprecedented levels, considering that the voters witnessed a judge controlling every ballot box, vote counting, and officially announcing the results on site.

The first election to be held under the new judicial supervision was a few months later in October 2000. The differences between this election and the previous ones (of 1990 and 1995) may be can be noted through the official results, which reflected the return of the Egyptian opposition back to the National Assembly including 17 seats to the Muslim Brotherhood (increasing to 88 seats in 2005 elections). ${ }^{10}$ Another indication to the extent of change that the judicial management of polls has caused is the turnout percentage. While was recorded consecutively $46 \%$ and 50\% through the 1990 and 1995 elections (managed by the security apparatus), the percentage was recorded $28 \%$ and $25 \%$ in the 2000 and 2005 elections (managed by the judiciary). The discrepancy between these percentages may be seen as an indication of the level of fraud practiced by the government in the elections during the nineties, reflecting unreal turnout numbers, whereas in the 2000's elections the numbers may be considered to more accurately reflect the real public opinion ${ }^{11}$.

As the government did not well receive the developments that the judicial supervision had caused, with regard to elections generally (with 2000 and 2005 parliamentary elections, and 2005 presidential elections in mind), the government took an unprogressive step by amending 34 Articles of the then 1971 Constitution, including Article 88 annulling judicial supervision for elections. This step gave its fruits in late 2010 parliamentary

10 Political participation in 2005 parliamentary elections. Samer Sulieman: 91 and 92. http://www.mosharka.org/index.php?newsid=172.

11 Political participation in 2005 parliamentary elections. Samer Sulieman: 31. http://www.mosharka.org/index.php?newsid=172. 
elections where the government completely controlled this election and totally excluded all opposition parties and movements from reaching the seats in the People's Assembly. No wonder this election, and the public frustration it had caused on a wide scale, is considered a factor, among others, that triggered the January 25 th revolution, a few weeks later.

As expected, and as a result of the demands of the political forces after the 2011 uprising, the judicial management for elections was restored (by every constitutional arrangement post-January 2011) and all electoral processes since March 2011 public referendum have been fully supervised by the judiciary.

\subsubsection{Dual nationality}

Another intervention by the SCC in the electoral processes relates to the candidacy conditions regarding parliament. Article 8.1 of the House of Representatives Law 46 of 2014 (HoR Law) conditioned holding the Egyptian nationality only. This provision, along with some others, was challenged constitutionally before the SCC which ruled that the restricted condition by the HoR Law is unconstitutional. The Court decided on the basis of the following reason:

"Whereas the provision of Article 102.2 of the [2014] Constitution has conclusively prescribed for the candidacy conditions for the House of Representatives, without ambiguity, that 'A candidate for the membership of the House must be an Egyptian citizen, enjoying civil and political rights." Thus, the constitutional legislator has set out the main and fundamental conditions so that the ordinary legislator may not derogate from it either by restricting or detracting it which may lead to emptying the constitutional texts of its content. These [candidacy] conditions included holding Egyptian nationality without any additional restrictions."

Hence, the SCC considered that the HoR Law, as it limited the candidacy to those holding the Egyptian nationality only, is restricting the candidacy conditions by depriving Egyptian nationals who additionally hold other nationalities from running for elections. The SCC thus opens the door to dual-nationals to run. ${ }^{12}$

12 See Case 24 for the 37th Judicial Year, Supreme Constitutional Court, session March $7,2015$. 


\subsection{The Supreme Constitutional Court's pre-enactment judicial review for electoral laws}

As stated earlier, the SCC's judicial review, for laws and regulations, has been always practiced after promulgations of laws and on the occasion of questions resulting from its implementation, in a specific judicial dispute. However, the SCC was tasked with conducting a pre-enactment judicial review in 2005 by a constitutional amendment. It was a presidential initiative by the then President Mubarak to amend Article 76 of the 1971 Constitution to allow pre-enactment judicial review of the electoral law for the first-ever pluralistic presidential elections. The amendment was approved by a public referendum. The newly amended Article 76.15 and 16 provides for:

"The President shall submit the draft law regulating the presidential election to the Supreme Constitutional Court following approval by the People's Assembly and before promulgation, in order to determine compliance with the Constitution.

The Court shall deliver its ruling on this matter within fifteen days from the President's submission. Should the court decide that one or more provisions of the draft law are unconstitutional; the President shall return it to the People's Assembly in order to bring the law into conformity with the ruling. In all cases, the Court's ruling shall be binding on all parties and all State authorities. The law shall be published in the Official Gazette within three days from the date of delivery".

Based on the above additional competency, the SCC scrutinized the Draft Law of the Presidential Elections 147 of 2005, before its promulgation, and issued its decision, on May 26, 2005, that five Articles of the draft law are unconstitutional $^{13}$. The legislature changed the unconstitutional articles and the law was then promulgated in line with the stipulated constitution prerequisites.

Assigning the SCC with this pre-enactment review for the presidential elections draft law was to guarantee that the law of the presidential elections - on which the incumbent of the highest office in the country is elected - is constitutional, and thus to exclude the possibility of deeming the presidential elections void, following a SCC verdict that the law is unconstitutional, which would lead to a constitutional crisis.

13 http://hrlibrary.umn.edu/arabic/Egypt-SCC-SC/Egypt-SCC-Decision.html. 


\section{Electoral disputes}

As mentioned earlier in the introduction, the SCC decides on the constitutionality of the electoral laws, whether before its issuance or after. The other side of the electoral issues in terms of relationship with the judiciary is the electoral disputes. Based on law and practice, these disputes can be classified into two categories: the first category includes the disputes over the legitimacy of the administrative decisions which organize the electoral processes; the second category of disputes concerns the validity of the parliamentary memberships.

In this regard, the Egyptian Court of Cassation stated that:

"The electoral disputes preceding the voting, votes counting and results announcing - which are the prerogative of the Court of Cassation - are according to their proper legal characterization, administrative disputes that shall be the Council of State's competent and not any other judicial body." 14

\subsection{The administrative judiciary (State Council)}

The administrative judiciary or the State Council has played a crucial role in electoral disputes since its establishment in the mid-forties. The State Council Courts' major competence is to review the administrative decisions' legitimacy; if proved illegitimate, it would abolish it.

The illegitimacy of the administrative decisions, if any, is based on some administrative theories and judicial precedents that have been developed over the years by the State Council Courts. Based on that "administrative decisions reviewing competence" the State Council Courts have issued numerous verdicts over the years invalidating electoral-related decisions issued by the election-management authority.

Following the same approach adopted by the Court of Cassation regarding defining its jurisdiction scope regarding elections, the Supreme Administrative Court (SAC), the highest court in the State Council body, sets the limits of its jurisdiction by stating:

"The administrative courts are competent to hear electoral appeals relating to the first stage of the elections which is the stage prior to the elections [election day] including, for example, adjudicating on the fulfillment of the

14 See Case 75 for the 85th Judicial Year, Court of Cassation, Civil Circuits, session June 27, 2016. 
candidacy conditions. The second stage, which starts with the announcement of results, is subject to the competence of the People's Assembly [which has to refer to the Court of Cassation, in this case] including, for instance, challenging the electoral process itself, or the appeals affecting the validity of the membership." 15

Among the many examples of electoral disputes that the administrative courts have dealt with, is the one that challenged the "official call for elections" decree. Before establishing the National Elections Commission in 2014, the legal tradition has been that the call for elections is issued by the President of the Republic. Based on the "Acts of Sovereignty" theory, the State Council Courts had been refusing to extend their jurisdiction to review such decrees, (to examine their legitimacy) including the call for elections decree. ${ }^{16}$ However, the Administrative Judiciary Court issued a landmark decision in 2013 which took a different approach. In February 2013, the then President of the Republic, Muhammad Morsi, issued the Presidential Decree 134 of 2013 calling for parliamentary elections to be held later in April 2013. Upon a challenge filed before the Administrative Judiciary Court, the Court deemed the President of the Republic's decree as void, and, hence, abolished it. The Administrative Court reasoned its decision, in refusing to consider the President of the Republic's decree as an act of sovereignty, by stating that:

"The legislature did not set a criterion, or define, the acts of sovereignty, rather, the judiciary itself has the mandate to define the scope of these acts as it should be interpreted as an exception, not the rule that every act (administrative decision) should be subjected to the judicial review. Additionally, the theory of sovereign acts cannot be applied if the administrative decision is in blatant contradiction to the constitutional provisions." ${ }^{17}$

Worth noting, finally, that the Administrative Court's decision in question was affirmed by a Supreme Administrative Court's decision. ${ }^{18}$ The parliamentary elections scheduled to be held in mid-April 2013 were completely cancelled, by virtue of this judicial decision, and Egypt did not see a new

15 See Case 25869 for the 5th Judicial Year, Supreme Administrative Court, session July $5,2008$.

16 See Case 3608 for the 38th Judicial Year, Administrative Judiciary Court, session May 8, 1984.

17 See Case 28560 for the 67th Judicial Year, Administrative Judiciary Court, session February 23, 2013.

18 See Case 13846 for the 59th Judicial Year, Supreme Administrative Court, session April 21, 2013. 
parliament until late 2015, after the dissolved 2012 People's Assembly, by a Supreme Constitutional Court rule.

\subsection{The Court of Cassation}

As stated previously, the Court of Cassation is the highest court in the general judiciary body. Since the 1923 Constitution, the tradition has been to assign the courts of the general judiciary (High Appellate Court and then, since 1931, the Court of Cassation) with the power to decide over the validity of parliamentary membership. This may have been because at the time of issuing the 1923 Constitution - which opens the door for the first-ever pluralistic parliamentary elections - the administrative and constitutional judiciaries were not established.

Before explaining the binding force of the Court of Cassation's decisions, the Court's precedents defined its competency to decide over the validity of parliamentary memberships stating that:

"The electoral challenge [over the validity of parliamentary membership] are the disputes over the results of the elections and the extent to which they reflect the genuine will of the electorate and the integrity of the electoral process against any fundamental flaw that affects the integrity or legitimacy of the procedures of voting, counting and declaring the results." 19

The nature of the Court of Cassation's reports or decisions, regarding the validity of the parliamentary membership, has been a controversial issue for decades, with two main tendencies ${ }^{20}$. The first trend describes the Court's decision as binding, and hence, the People's Assembly should abide by that decision if the court found that the challenged membership is void. On the other hand, some believe that the Court of Cassation's decisions/reports only have a consultative nature, and the final decision as to deem a membership invalid is in the hands of the discretionary power of the parliament.

19 See Case 3249 for the 58th Judicial Year, Court of Cassation, Civil Circuits, session February 28, 1990.

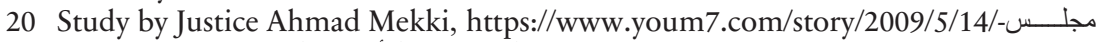

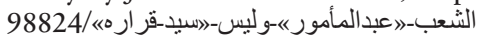


The 1971 Constitution in Article 93 addressed this competency of the Court of Cassation:

"The People's Assembly shall be the only authority competent to decide upon the valid election of its members.

The Court of Cassation shall be competent to investigate contestations of an election presented to the Assembly, upon referral by the President of the Assembly.

The contestation shall be referred to the Court of Cassation within fifteen days from the date of its submission to the Assembly, and the investigation shall be completed within ninety days from the date on which the contestation was referred to the Court of Cassation.

The result of the investigation and the conclusions reached by the Court shall be submitted to the Assembly for a decision upon the validity of the contestation within sixty days from the date of submission of the results of the investigation.

The membership will not be deemed invalid except by a decision taken by a majority of two-thirds of the Assembly members".

The Article paved the way for a four-decades-long controversy over the nature of the Court of Cassation's reports as it granted the Court of Cassation the authority to investigate the electoral process that may lead to deeming the election of a specific district as void; however, the final authority to decide on the validity of the membership lies in the hands of the People's Assembly itself. In practice, when the Court of Cassation reported electoral violations in specific electoral districts, the People's Assembly did not, in the vast majority of cases, consider the Court of Cassation reports, which lead to waves of criticism of the People's Assembly's policy over years because of overriding the Court's reports, even though the latter is not constitutionally binding. The People's Assembly Speaker in the late eighties had initiated a famous quote on the subject issue stating that: "the Assembly is the master of its decisions" or "Al-Majlis Sayyed Kararoh".

After the 2011 uprising, the constitutional declaration of March 2011, in Article 40, has adopted what many scholars and politicians had been calling for, to authorize the Court of Cassation with a decisive and binding authority over the validity of parliamentary membership. Later in 2011, the SCAF had issued Law 24 of 2012 of the challenge procedures before the Court of Cassation on the validity of membership of the People's Assembly. The current 2014 Constitution then followed the same approach and prescribed in Article 107, which states that: 
"The Court of Cassation has jurisdiction over the validity of membership of members of the House of Representatives. Challenges shall be submitted to the Court within a period not exceeding 30 days from the date on which the final election results are announced. A verdict must be passed within 60 days from the date on which the challenge is filed.

In the event a membership is deemed invalid, it becomes void from the date on which the verdict is reported to the House."

The first post-2014 Constitution parliamentary elections in Egypt took place in late 2015, where many challenges were submitted to the Court of Cassation appealing for invalidating some parliamentarian's memberships. The most controversial electoral dispute was the challenge by Dr. Amr AlShobaky against his opponent in the Al-Dokki district. The Court of Cassation ruled for Al-Shobaky by invalidating the High Committee for Parliamentary Elections decision which announced his opponent's electoral victory and affirmed the validity of Al-Shobaky's membership. ${ }^{21}$ However, and despite the binding nature of the Court of Cassation's decision, Amr Al-Shobaky has not been able to enter into parliament for around two years, while his ex-opponent, with his void membership, still represents the Dokki district in the parliament. The responsibility for such overriding of the Court of Cassation's decision is on the House of Representative and his speaker's side. ${ }^{22}$

\section{National Elections Commission}

A long-standing demand by the political parties and forces in Egypt had been to establish an independent High Commission/Committee for managing all electoral processes. Before the current 2014 Constitution, the case had been to establish an electoral committee for each election. Even though each committee has the same name, as the High Committee for Parliamentary Elections or the Presidential Elections Committee, the organigram and management staff was different from one election to another. This setup did not help in maintaining the institutional memory of various election committees. Examples of these various committees are those established by Law 174 of 2005 instituting presidential elections

21 See Case 75 for the 85th Judicial Year, Court of Cassation, Civil Circuits, session June 27, 2016.

22 http://english.ahram.org.eg/NewsContent/1/64/248934/Egypt/Politics-/Egypt-parli ament-delays-seating-of-MPelect-Amr-ElS.aspx. 
committee that managed the 2005 elections with various amendments to the law until its replacement with the current Law 22 of 2014. The same applies to the Parliamentary Elections High Committee.

The current Constitution of 2014, in Articles 208, 209 and 210, established the National Elections Commission (NEC) and mandated it with managing all electoral processes to be held after its establishment. Article 208 provides for:

"The National Elections Commission is exclusively responsible for managing referenda and presidential, parliamentary and local elections, which includes the preparation and update of a database of voters, proposal and division of constituencies, setting regulations for and overseeing electoral campaigns, funding, electoral expenditure declaration thereof, and managing the procedures for out-of-country voting by expatriate Egyptians, and other procedures, up to the announcements of results".

Based on the above constitutional text, the HoR issued Law 178 of 2017 for the National Elections Commission that abolished the High Committee for Parliamentary Elections (organized in HoR law) and the Presidential Elections Committee (as in the Presidential Elections law).

The relationship between the judiciary and the NEC can be tracked in the following three issues:

1. The NEC members are all judges or members of judicial bodies, Article 209 of the Constitution organized the NEC membership: "The National Elections Commission is administered by a board made up of 10 members selected equally from among the vice-presidents of the Court of Cassation, the presidents of the Courts of Appeal, the vice-president of the State Council, the State Affairs and Administrative Prosecution, who are to be selected by the Supreme Judicial Council and special councils of the aforementioned judicial bodies depending on the circumstances, provided that they are not members in them. They are appointed by a decree from the President of the Republic. They are selected to exclusively work at the Commission for one term of at least six years. The Commission's presidency belongs to its most senior member from the Court of Cassation. Half of the members of the Council are replaced every three years. The Commission may refer to public figures, specialists, and those deemed to have relevant expertise in the field of elections. They do not have the right to vote."

2. The affiliated members of the NEC, who are assigned to run the general and sub-committees during the election days are members of judicial bodies. This constitutes a continuation of the policy adopted in 2000 as explained earlier in this chapter. However, Article 210 states that: 
"Voting and counting of votes in referenda and elections run by the Commission is administered by its affiliated members under the overall supervision of the Board. It may use the help of members of judicial bodies. The voting and counting of votes in elections and referenda in the 10 years following the date on which this Constitution comes to effect are to be overseen by members of judicial bodies and entities in the manner set out in the law." This Article opens the door to abolish judicial supervision of elections starting from the year 2024, as it obliges the NEC to assign the judicial bodies members with elections overseeing only for 10 years starting in 2014.

3. Finally, Article 2103 of the Constitution authorized the Supreme Administrative Court (SAC) to decide upon the challenges against the NEC decisions "pertaining to referenda, presidential and parliamentary elections, and their results. Challenges against local elections are to be filed before the Administrative Court. Dates to file challenges against these decisions are specified by law, provided that challenges are finally adjudicated within ten days from the date of filing them."

\section{Concluding remarks}

Having illustrated and discussed the role that has been played over decades by various courts concerned with electoral disputes in Egypt, a trend to increasing and definite judicial control of elections can be noticed, the final word of Supreme Administrative Court on decisions of the National Election Commission's decisions being just on example. This trend is supported by the Supreme Constitutional Court's jurisdiction over the past decade, who plays a decisive role in it, as has been exemplified in this chapter. 